\title{
China's Pursuit of Soft Power: Norm Diffusion as a Soft Power Mechanism
}

\author{
Xing Li \\ Research Center on Development and International Relations, Department of Politics and Society, Aalborg University, \\ Aalborg East, Denmark \\ Email: xing@dps.aau.dk
}

How to cite this paper: Li, X. (2020). China's Pursuit of Soft Power: Norm Diffusion as a Soft Power Mechanism. Advances in Applied Sociology, 10, 278-297. https://doi.org/10.4236/aasoci.2020.107017

Received: November 26, 2019

Accepted: July 27, 2020

Published: July 30, 2020

Copyright $(\odot 2020$ by author(s) and Scientific Research Publishing Inc. This work is licensed under the Creative Commons Attribution International License (CC BY 4.0).

http://creativecommons.org/licenses/by/4.0/

\begin{abstract}
The objective of the paper is to provide a framework for conceptualizing and discussing Chinese soft power against the background of China's global rise. The paper argues that China's goal in enhancing and strengthening its global soft power status is being realized, not through a national strategy of deliberate promotion, but through the "causal" effect brought about by the Chinese model of economic rise and the country's increasing role in international institutions. This Chinese strategy is identified as "norm diffusion as a soft power mechanism". The paper compares the historical evolution and the institutional normative basis of the US hegemony and finds some similarities with the present Chinese experiences. The paper posits that China's hard power (economic success in production, trade, finance, and foreign aid) is paving the way for the diffusion of Beijing's normative power, and such norm diffusion becomes the source of emission and attraction of China's soft power in terms of shaping perceptions, cognitions, and preferences among international actors.
\end{abstract}

\section{Keywords}

Soft Power, Norm Diffusion, Hegemony, International Institutions

\section{The Research Proposition, Objective and Conceptual Understanding}

The concept of "soft power" in Nye's words is "associated with intangible power resources such as culture, ideology, and institutions" (Nye, 2009). He regards soft power as a kind of attractive and persuasive power, which rests on attraction and emulation. However, Nye's perception of how soft power plays its due role raises several questions. The first question that challenges Nye's soft power depiction is whether the form of soft power is a product of given sources, such as 
culture, socio-political values and foreign policy, or whether it is a byproduct of the reflection and the extended consequence of material and hard powers. The second question concerns the causal mechanisms through which the role of soft power is to be understood. For example, are norms and the legitimacy of international organizations the outcome of shared values and ideologies, or rather, are they shaped by the hegemonic structural power of the US? The third question asks whether soft power is a dependent or an independent variable. In other words, does soft power play a distinctively independent role or merely a proxy role in a country's goal to become a global attractive and persuasive power? The last but not least important question concerns the diffusion mechanism that promotes or leads to soft power improvement.

To place China in the context of the above questions, the paper proposes that the advancement in China's global soft power status is not the result of a national strategy of deliberate promotion, such as the expansion of the Confucius Institute. Rather, it is a "causal" outcome brought about by the increase in China's global economic success in general and the normative "diffusion" effect generated by its global institutional role in particular. The key logic underlining the paper's arguments is based on the following causal relationships:

1) China's hard power achievements materialize the increase of its normative power because of the active global institutional role played by China and the attractiveness of the Chinese development model. This implies that it is important for a rising power to be internationally recognized, not only in terms of the material, or objective aspect of agency, but also in terms of the subjective, or ideational aspects attached to the agency. In other words, the importance lies in "the practice of discursive representation" (Diez, 2005), i.e. the construction of a normative image.

2) Normative power denotes or represents a certain type of actor in international relations. It is understandable why Beijing has been struggling to project itself as a global responsible stakeholder, a status quo power, not a revisionist one. However, the focus taken by soft power approach is less on what type of actor China is, and more on the type of instruments and tools that are applied by China in the process of becoming a global power.

3) Since international institutions shape norms and normality, policies and polities, they are seen to be dominating in contexts where concepts of power, legitimacy, and responsibility within a framework of international society are being practiced (Clark, 2014). In the past decade, China's assertive and proactive roles within existing international institutions as well as in the setting up of new global financial institutions have shown China's great transformation from a norm-follower to a norm-maker. Today, Beijing is in a position to influence the norms of international society in one way or another.

4) The diffusion of the Chinese norm-shaping power is conducive to the promotion and enhancement of its soft power. The paper emphasizes that the emerging role of norm diffusion is underpinning China's soft power development-"soft power with Chinese characteristics". In other words, the soft com- 
ponents of Chinese policies, norms, values, and institutions will be strengthened and will be intertwined in the emerging world order as a result of the diffusion outcome achieved by China's global economic rise and its increasing institutional roles.

The author argues that the current worldwide literature on China's ascendance focuses mainly on its hard power achievements, i.e. its military, political, and economic power, without paying much attention to Beijing's soft power accomplishments. Global discussions on Chinese soft power are very often inclined to view China's use of soft power resources as a way to assert its influence abroad and to project its great power status. The author maintains that at the present time, it is imperative to study China's soft power achievements brought about by its emerging "normative power" in the world order, even though the notion of "China as a normative power" might appear provocative and controversial, especially within the mainstream of social sciences where paradigms and discourses have been defined by Western powers. China's foreign policy practices are often judged with regard to their compliance with Western normative standards. This paper sees the relationship between normative power and soft power as "normative soft power" (Callahan \& Barabantseva, 2012) because these powers are each other's enforcement ingredients.

The objective of the paper is to disclose the causal and mutual reflective nexus between China's hard power and normative soft power by providing lines/areas/ideas of conceptualizing and analyzing three dimensions of the Chinese soft power discussions: 1) The sources of Chinese soft power cannot be separated from the country's material hard power, and Chinese soft power is a byproduct or a causal outcome of China's material and structural power; 2) China's soft power accomplishments are diffused by global attraction to its economic success - the "Chinese model" - with its cultural and historical "embeddedness" ( $\mathrm{Li}, 2016 \mathrm{a})$; 3) Chinese soft power is promoted and enhanced through norm diffusion as a soft power mechanism, as a result of its active role in international institutions.

Conceptually, the paper argues that, contrary to Nye's emphasis on soft power's independent role (Nye, 2005), hard power and soft power are two sides of the same coin, i.e. they are mutually complimentary and cannot be separated. Seen from the author's perspective, soft power is a product of a particular movement, whereas hard power is the basis of the growth and functioning of a country's soft power, allowing the country to decide how it will play its hard power in shaping and modulating soft power. Accordingly, the paper maintains that although the concept of soft power denotes conscious awareness and a cognitive idea, it is not a concept empty of substance. Rather, it is based on a terrain of practices, principles, and dogmas of a material and institutional nature. In other words, it rests on the material basis of hard power, and hard power constitutes the precondition under which soft power can unleash its full potential.

The author's understanding of the hard power-soft power nexus is related to the Gramscian notion of hegemony (Gramsci, 1971) that coercion (material and 
hard power) and consent (ideational soft power) are in practice inseparable. According to the author's analysis, the Chinese global soft power strategy is aiming to approach its ultimate objective by winning a favorable normative position in the world order. Seen from today's perspective, the Chinese strategy is to "win a favorable position" through becoming an indispensable rule-maker with norm-setting and norm-shaping power in international financial institutions. Consequently, China is arguably in the process of becoming an emerging normative power that is able to influence the policy behavior and attitudes of other states through its hard power attraction (trade, investment, commodity prices, tourist market, etc), especially in the developing world (Li, 2016b). Today, China is making an effort to socialize various actors into the "Chinese way of doing things" and integrate them into the current international institutionalized structures and China-led international development projects.

The paper is structured as follows: The first section explores the strategy through which China is developing its global soft power capacity and recognition. Beijing's strategy is to establish itself as an emerging normative power (rule-initiator and rule-maker) by using its economic power to build alternative international financial institutions. The second and third sections explain the historical trajectory and lessons of the US hegemonic evolution, and emphasize the interplay between hegemony (hard power + normative soft power) and international institutions as diffusion mechanisms. The Chinese strategy to achieve and expand its soft power shows a similar pattern. The third section discusses the relationship between hard and soft power through the lens of the Gramscian and Neo-Gramscian IR concepts of "hegemony". The fourth section analyzes the outward expansion of China's economic weight and the country's financial impact, which is generating an emerging phenomenon of global "interdependent hegemony". In the current era of "interdependent hegemony", the existing powers (the US in particular) and the emerging powers (China in particular) are intertwined in a constant process of shaping and reshaping the international order in the domains of both hard power (representation, voting and decision-making) and normative soft power (soft power components in terms of policy-negotiation, norm-making and rule-setting). The final section summarizes the key conclusive implications.

\section{China's Approach to Soft Power: Norm Diffusion as a Soft Power Mechanism}

It is crucial to understand how soft power sources are generated from norm diffusion, such as from foreign policies and economic success. Norms can be diffused through either teaching or learning processes or through the successful demonstration of the norms in practice; and successful demonstration will furthermore enhance the prestige, credibility, and acceptance of the receiver or implementer of a norm (Rothman, 2011).

Seen from the author's understanding, Beijing's approach to increasing and 
strengthening its soft power reflects its primary intention to establish itself as an international "normative power" in a changing world order. The term "normative power" was originally coined by Ian Manners to describe the distinct role of the EU in the international system. Manners defines a normative power as a power that "shape[s] the conceptions of the normal" (Manners, 2002). And most literature on normative power explicitly or implicitly applies the EU as "normal" reference. Recognizing the fact that the idea of a "Normative Power China" might sound like a "misnomer" as China's foreign policy practices are often judged in compliance with Western normative standards, Kavalski (2013a) compares "normative power Europe" with "normative power China”, emphasizing the importance of being recognized as a normative power by others rather than being/becoming a normative power.

For example, the China-led Asian Infrastructure Investment Bank (AIIB) can be regarded as Beijing's first involvement in norm-setting and rules-making in global governance on the world stage (Feng \& He, 2015). Peng and Sow directly identify AIIB as "China's normative power in international financial governance", and they summarize their analyses and arguments as follows:

Based on the existing framework of normative power concept, the AIIB's role in China's normative power is examined from three angles: normative principles, norm diffusion, and external perception. As a Chinese initiative, the AIIB's policy framework has inherited Chinese norms of unconditionality and infrastructure construction. The management structure of this new bank also manifests China's preference of a lean internal arrangement. Moreover, Asian developing countries hold the majority of voting power of the AIIB. This distribution of votes also falls in line with China's appeal of a fair governance structure in international financial institutions. (Peng \& Sow, 2016)

Thus, the importance of the AIIB should not be judged on whether or not its institutional design provides adequate voice to major shareholders; rather, the importance should be understood from its norm-setting effect, i.e. the ideational differences in methods to address global structural problems such as the fostering of economic development in underdeveloped areas (Strand et al., 2016). The normative value of the AIIB is that it brings about a global consensus or a shared belief that infrastructural demands represent the core development challenge, especially for developing countries. The AIIB is a clear indication that confirms the projection that Beijing's path to becoming a global power is focused on increasing its roles in international organizations while seeking to gain a "norm-setting" status in the international system (Lanteigne, 2005).

In a similar vein, a number of scholars are also looking at the nexus between normative power and soft power in the context of China's global rise. The notion of "normative soft power" coined by Callahan and Barabantseva (2012) brings together Chinese and Western analyses in the nuanced exploration of the way in which traditional Chinese culture and history are being remolded into a world 
order with Chinese characteristics. This paper looks through the analytical lens of the neo-Gramscian interpretation at the nexus between the US hegemony and world order, applying the understanding that the rise of a nation's soft power can be scrutinized by examining the extent of its occupation with the normative constituents of the global governance structure that underpins the existing world order. Obviously, international institutions are the sources of normative power through which a nation's global position can be assessed, in terms of both hard power (material capacity and economic power) and norm-based soft power (norm-defining, rule-making and agenda-setting).

\section{Normative power and soft power}

Although normative power and soft power have different conceptual connotations, they are also inherently connected. The conceptual nexus between normative power and soft power is identified by Nye's first paper on soft power, in which he argues that soft power, as a kind of intangible power, consists of three key elements, i.e. cultural attraction, ideology, and international institutions (Nye, 1990). Nye links the notion of soft power to international norms and institutions in the following way:

If a state can make its power seem legitimate in the eyes of others, it will encounter less resistance to its wishes; if its culture and ideology are attractive, others will more willingly follow; if it can establish international norms consistent with its society, it is less likely to have to change; if it can support institutions that make other states wish to channel or limit their activities in ways the dominant state prefers, it may be spared the costly exercise of coercive of hard power. (Nye, 2004)

The connection between normative power and soft power is also shared by some Chinese scholars. Yan Xuetong (2007) maintains that "soft power lies in political power that is exclusively found in political institutions, norms and credibility". Another Chinese scholar, Zhu Feng (2007), maintains that "soft power has little to do with the sources of power but with whether the international community accepts a nation's policies and strategic choices, and with the extent those choices accord with most the nation's interests."

The normative constituents of China's soft power are not easily defined in a specific way, but these objective norms are conducive to the subjective soft power of attraction. Many components of Chinese "normative adherence" or "normative promotion" characterize the discursive elements of Chinese soft power, such as 1) the Chinese foreign policy of non-interference ${ }^{1}$ (respect for national and territorial sovereignty); 2) the Chinese foreign aid policy of non-conditionality (no political precondition for receiving international aid); 3) the Chinese cultural diplomacy to promote a "harmonious world" (respect for pluralism in so-

${ }^{1}$ It is part of Chinese foreign policy principles, see Chinese Ministry of Foreign Affairs “The Five Principles of Peaceful Co-Existence: Fundamental and Everlasting Norms Guiding International Relations,"

<http://www.fmprc.gov.cn/mfa_eng/topics_665678/seminaronfiveprinciples_665898/t140589.shtml> [2 May 2018]. 
cio-cultural and econo-political systems); 4) the Chinese global vision of a "community of common destiny for humankind" (global interconnectness, economic interaction and interdependence, peaceful coexistence, cooperative win-win development), etc. These normative features underlining China's foreign policy and diplomacy are intentionally aiming at "offering to the pluralistic world a non-Western alternative that features new thinking and practice" (Yang, 2015). Currently, they are being practiced through China-centered institutional mechanisms of international finance, international cooperation and regional and global governance.

One particular source of the Chinese soft power of attraction is the normative diffusion of the model of China's economic success-the "Beijing Consensus"including the key normative principles of policymaking that challenge mainstream global politics resting on the normative principles of liberal democracy and market fundamentalism. The Chinese development model and its normative value of "embeddedness" ( $\mathrm{Li}, 2016 \mathrm{a}$ ) is resulting in the flow of ideas and the mainstreaming of its own values among international actors. This is what political sociologist Steven Lukes (2005) perceives as the third dimension of his view on power, i.e. shaping the perceptions, cognitions, and preferences of others, which is an essential trait of soft power. A recent article in the Wall Street Journal openly admits that "the democratic cause is on the defensive today, and China's pragmatic authoritarianism now offers a serious rival model, based on economic progress and national dignity" (Runciman, 2018).

The "Belt and Road" initiative is China's latest macro project in which Chinese policy norms are to be practiced. According to one concrete study, normative matrices and decisions in countries involved in the "Belt and Road" initiative are influenced by the thinking and practices of Chinese policymakers and intellectuals, and such a process of internalization of external policy norms is identified as a process of "policy-principle diffusion" (Vangeli, 2018). This fully reflects Joseph Nye's understanding of soft power as the ability "to achieve goals through attraction rather than coercion," and as the ability to get "others to want the outcomes that you want" (Nye, 2005). The "Belt and Road" process is driven by dual aspects, with China primarily on the normative supply-side and other recipient actors ${ }^{2}$ on the demand side. In other words, the impact of China's "Belt and Road" project should be understood as not only Beijing's "offer", but also as what regional actors make of it (Vangeli, 2018).

Normative soft power via "war of position" in global financial governance

A "war of maneuver" and a "war of position" are the two important concepts coined by Antonio Gramsci (1971). The former refers to a direct, violent and immediate assault on the status-quo power structure, while the latter implies a slow and protracted strategy of political struggle aimed at undermining the influence and foundation of the existing leadership. During the early period, Beijing's international soft power policy was predominantly led by "war-of-maneuver" ${ }^{2}$ It particularly refers to the 16 countries of Central, East and Southeast Europe. 
tactics, and this remained an unsystematic and defensive practice with random reactions towards self-justifying China's domestic and foreign policies against the US and the West on particular issues of dispute, such as democracy, human rights, Sudan, Myanmar, the Falun Gong Organization, the Muslim minorities. Such a tactic has been counter-productive because China has always been in a position of the passive defender against the international norms and standards in which China was not one of the rule-makers. In addition, much criticism is targeted at Beijing's efforts to acquire soft power through centralized schemes, such as the Confucius Institute, and the China Public Diplomacy Association.

In recent year, a clear change of China's soft power approach has been seen. Beijing understands that global governance presumes the validity of a number of norms rooted in Western experience, such as free market competition, human rights, democracy, transparency, accountability, and the rule of law, and that it must apply different strategies to approach different issues. Currently, China is adopting a war-of-position strategy in occupying a pivotal position in global governance as a new and alternative provider of global financial public goods, thus becoming an emerging rule-maker in the setting of norms and standards. Offering more loans than the World Bank, China is today the world's largest provider of finance and the most proactive investor in infrastructure in developing countries.

Since Nye's soft power framework stresses the "normative" appeal of policies and practices that reflect global preference, the global expansion of Chinese financial role in general, and the Chinese "Belt and Road" project and the Beijing-led AIIB in particular are regarded as indications that Beijing is moving towards providing alternative public goods in the world economy, which is a key precondition for becoming a global economic normative rule-maker. The recent decision by the International Monetary Fund to include the Chinese currency (RMB) in the Special Drawing Rights (SDR) basket is paving the way for a broader use of the RMB in global trade and finance, securing China's standing as a global economic power. However, for the Chinese RMB to become part of the IMF's SDR, not only a strong economy and finance (hard power) is required; a sound and transparent system of norms, rules and institutions (soft power) is also necessary in order to persuade the world to hold its assets and currency. Once China's internal financial reform became successful, it would unleash a great deal of soft power potentials shaped by Beijing's financial policies, which would have an important impact on the economies of millions of people beyond China's borders.

The outward expansion of Chinese hegemony driven by its growing economic weight and global financial role is inevitably generating a great impact on the existing global governance structure, not only in the system's organizational constituents in terms of representation, voting and decision-making (hard power), but also in its normative components in terms of policy-negotiation, norm-making and rule-setting (normative power). Beijing's important role in global financial governance is instrumental in designing and projecting its power of "influence", 
and the influence over others is an important aspect of soft power.

Globally, the Chinese "Belt and Road" initiative has been interpreted as Beijing's "soft power" initiative aimed at influencing and shaping the political and economic landscapes of East and Southeast Asia, Eurasia and Africa over the coming decades (Winter, 2016). The Belt and Road initiative was designed on the basis of an inter-connected regional network of market integration in infrastructure partnership, in the commodity and energy sectors, and in telecommunication projects. Heuristically, it brings people back to the historical past of the ancient "Silk Road" between East Asia/China and Europe, in which peaceful trade with religious and cultural exchange represents the legacy of a historical memory. Beijing's Belt and Road initiative is seeking to establish itself directly on the narrative linkage between cultural understanding and economic prosperity, and the initiative serves as a medium of non-coercive diffusion of policy principles rooted in state-led economic cooperation. Based on the Chinese principle of respecting the national sovereignty and the nation's choice of development path, the OBOR initiative at the same time facilitates norms, ideas and principles of policy-making that have the potential to affect the behavior of others and alter their trajectory (Vangeli, 2018).

\section{Reflecting the Evolution of US Hegemony: From Hard Power to Normative Soft Power}

The discussion on the nexus between Chinese hard power and normative soft power in the previous sections can well be reflected by the historical evolution of the US hegemony and the US-led world order since the end of the Second World War. Although it is slightly more complex to analyze the Chinese case in the current era of a changing world order, both the US and Chinese cases show the linkage between a state's internal power accumulation and consolidation of hegemony and its external power projection aimed at shaping the regional and global orders. Moreover, China's outward power expansion shows a similar pattern of transformation from being a normative power constructing and shaping international institutions to becoming a persuasive power of attraction and emulation.

Nye's original articulation of soft power in the early 1990s intended to explain a historical movement in the US global leadership and to provide post-Cold War justification of the shift of power application strategies from state-centered hard power competition to soft-power promotion in public diplomacy. His attempt was to suggest a foreign policy reorientation aiming at relying more on non-coercive forces in line with those which presumably undermined the Soviet Bloc, such as the norms and values of Western democracy, freedom and lifestyles. Thus, the notion of soft power is a product of a particular historical movement that helped fill the ideological gap left by the end of anti-Communism. Soft power is only one side of hegemony, and it is not the end but an important supportive means to achieve and maintain US hegemony in the world order. 
How was the US able to maintain its hegemony? A good analytical tool to understand this question is the neo-Gamscian IR theory, which is a critical theory of understanding the relationship between hegemony, world order, and historical change. Such a nexus explains how internal hegemony, driven by dominant class and social forces occupying leading positions within a nation state, is then extended and projected outward on a world scale, leading to the shaping of the international order (Cox, 1981, 1983). This neo-Gramscian understanding of hegemony is a holistic and structural understanding of power and order reflecting a manufactured interplay between ideas, material capacities and institutions.

Based on his empirical observations, Cox noticed that the world order under which US hegemony could be sustained was structurally produced and reproduced by the US-led international organizations (the Bretton Woods system) together with its allied regimes, which enabled the US and its dominant class of collective actors to perpetuate their favorable position in the world order and to shape the development direction of the system in general. Nye also points to the importance of international organizations as an important component of his soft power concept:

Institutions can enhance a country's soft power. For example, Britain in the nineteenth century and the United States in the second half of the twentieth century advanced their values by creating a structure of international rules and institutions that were consistent with the liberal and democratic nature of the British and American economic systems: free trade and the gold standard in the case of Britain; the International Monetary Fund, the World Trade Organization, and the United Nations in the case of the United States. (Nye, 2004)

However, Nye ignores the historical fact that the entire architecture of the post-war international organizations was shaped by the US in order to set up international rules that were consistent with US interests. International institutions were primarily established to serve the interests of the American economy, which was heavily dependent on the functioning of the capitalist world system. Nye forgets that the post-war history of international relations in general and of international organizations in particular shows that they were not really founded and shaped by soft power idealism (norms and values, and cultural leadership), but rather, by hard power necessities (politics, economics and security) and for hard power purposes (dominant position). The hard power of a hegemon is supposedly to shape institutional norms and values deemed by the hegemon as "universal". In return, these universal institutional norms and values will continuously facilitate the rules of game that perpetuate gross structural inequalities and disparities of wealth and power in the world order.

The Chinese soft power strategy in many ways resembles the Gramscian notion of "war of position". Cox (1983) sharply describes the "war of position" as a process that "slowly builds up the strength of the social foundations of a new state" by "creating alternative institutions and alternative intellectual resources within the 
existing society". Hence, the paper specifically suggests that in the discussion of China's soft power, the neo-Gramscian IR theory offers an insightful approach to identifying hegemony (hard power + soft power) as the outward power expansion of its internal pattern of hegemony in shaping the world order. In line with this perspective, soft power can be seen as a causal expansion of hard power. The neo-Gramscian IR theory emphasizes the interconnection between hegemony, world order, and historical change (Cox, 1981). Such a nexus explains how internal hegemony, driven by the dominant class and social forces occupying a leading position within a nation-state, is then extended and projected outward on a world scale, leading to the shaping of the international order.

The paper's thematic discussions on Chinese soft power and the heuristic comparison with the US case invite us to rethink the mainstream concept and use of soft power coined and defined by Joseph Nye. His initial soft power concept can be understood as an outcome derived from the victory of the Cold War, in which the ideal of liberal democracy was claimed to defeat the communist dictatorship. The collapse of the Soviet bloc seemingly provided the strongest proof of Nye's "power of persuasion and attraction". In world history, it is not a new phenomenon that power always consists of hard and soft power, and soft power has always been a companion of hard power in fulfilling its due roles. However, as some scholars have pointed out, treating soft power, i.e. persuasion, influence and attraction, as an effective way to advance strategic interests is a relatively new phenomenon (Simonyi \& Saunders, 2015). Unfortunately, the triumphalism of the Cold War has produced two myths: the exaggeration of the superiority of soft power (value, system and ideology), and the understatement of the role of the decisive possession of effective hard power in winning the Cold War (Simonyi \& Saunders, 2015).

Nye's idea of soft power as a type of persuasive power based on attraction and emulation seemingly implies that soft power does not necessarily depend on hard power, but can play an independent role. In contrast to Nye's soft power understanding, Huntington emphasizes that material success and hard power foundation are the preconditions for soft power to play its due role:

What, however, makes culture and ideology attractive? They become attractive when they are seen as rooted in material success and influence. Soft power is power only when it rests on a foundation of hard power. Increases in hard economic and military power produce enhanced self-confidence, arrogance, and belief in the superiority of one's own culture or soft power compared to those of other peoples and greatly increase its attractiveness to other peoples. Decreases in economic and military power lead to self-doubt, crises of identity, and efforts to find in other cultures the keys to economic, military, and political success. (Huntington, 1996)

Huntington's message strongly indicates that if a country's culture and ideology are attractive, thus inviting other countries to follow and imitate these, this country must first and foremost demonstrate its material success. 
Nye's idea of soft power's independent role clearly contradicts the basic tenets of Gramscian hegemony claiming that coercion (hard power) and consent (soft power) are in practice inseparable. In line with the Gramscian understanding, consensual power (soft power) is important, but it cannot be achieved at the cost of sacrificing the means of dominance (hard power). This is to say that the consensual compromise (Gramsci's "passive revolution"), which is necessary for the dominant class to sustain hegemony, must not challenge the economic order (material foundation) on which the hegemony of the dominant class is based. Losing the economic order will result in the loss of the reproduction of the existing mode of production which a dominant class uses to create the material basis required to sustain its hegemony and to "satisfy" the consent of the subordinate classes. The Gramscian hegemony theory offers us a useful tool to draw a combination line between hard power and soft power, while placing a heavier emphasis on their amalgamation into tangible hegemony.

In explicit ways, Nye's soft power concept is closely linked with the central aspects of the Gramscian notion of hegemony, such as the combination of coercive submission and consent cooptation, and the material basis of ideology. Such a notion implies that the power of the elite groups manifests or responds to the wide-ranging apparatus of norms, values, and practices that produce and reproduce the ruling legitimacy in line with socio-cultural and socio-political institutions and culture. To Gramsci, ideology (idea, norm and value) is not "something which, as it were, floats in the air high above the political and other practical activities of men and women" (Simon, 1982); rather, it has a material existence in these activities. Saying that ideology has a material existence indicates that it is embodied in individual practices and in the political and economic institutions in which these practices occur. Likewise, soft power can be conceived as "the diversity of idealizations that are linked to particular political imperatives and historical contingencies" (Hayden, 2012).

The concept of "hegemony" is often applied to describe different enduring aspects of an order in the international system. It is a useful instrument in conceptualizing and understanding the dynamic and dialectic interplays in the world order and in international relations/systems. Realism perceives hegemony as the dominance by one leading state in interstate relations, as reflected in the concept often used by realism: "hegemonic stability" (Kindleberger, 1973; Gilpin, 2001). Neo-liberalism sees hegemony as embedded in the interactions of each individual at the bottom, and in the norms and values of neoliberal institutionalism (Keohane, 1984). Moreover, the world system theory emphasizes state-based class and material forms of hegemony which are shaped and maintained by a global division of labor. This division of labor constantly generates and regenerates unequal exchange, which in turn causes differentiation between the strong/rich versus the weak/poor, not only economically, but also politically and in terms of military status (Wallerstein, 1979, 2004).

The notion of hegemony in international relations is understood by the 
neo-Gramscian IR theory as a capacity to transfer national patterns of power relations (mode of production, and socio-economic and socio-political relations) to international arenas, shaping the world order (global governance) around particular state-market-society interactions (Cox, 1981, 1983). By no mistake, the "shaping" power is essentially hard power. The notion of soft power owes some conceptual debt to Antonio Gramsci's political theory of hegemony. The legacy of Gramsci's hegemony ideas can be found implicitly in Nye's work, although he does not explicitly identify his work with Gramscian and neo-Gramscian IR scholarships and theories.

\section{China's Normative Soft Power in the Age of Interdependent Hegemony}

Based on the above, the author also argues that the discussion on China's rise and soft power is linked with the contemporary global political imperatives and historical contingencies. Today, the world order is entering into a new era of "interdependent hegemony" ( $\mathrm{Li}, 2016 \mathrm{c}$ ), in which both the "First World" (the established powers, especially the US) and the "Second World" (the emerging powers, especially China) are intertwined in a constant process of shaping and reshaping the international order in the nexus of national interest, regional orientation, common political agenda, political alliance, and potential conflicts. Following Nye's definition of soft power as: 1) the ability to get "others to want the outcome that you want" (Nye, 2004) and the ability to shape the preferences of others; and 2) the attractiveness and particularly "the ability to achieve goals through attraction rather than coercion" (Nye, 2004), the author argues that China is presently unleashing a great deal of "soft power with Chinese characteristics", brought about by its economic success and the spill-over effects of this. These effects are being reflected and intertwined in the structural power of the existing world order.

First, "interdependent hegemony", or "intertwined hegemony", exemplifies the fact that global capitalism is entering into a stage of "varieties of capitalism" in which the existing and emerging powers are encountering clashes due to disagreements and conflicts of interest, leading to the weakening of the existing international regimes and the established normative structures. This implies that the world order is entering "the age of entropy", in which

Its [the order] old architecture [is] becoming creakier and more resistant to change. New rules and arrangements will be simply piled on top of old ones. And because there will be no locus of international authority to adjudicate among competing claims or to decide which rules, norms, and principles should predominate, international order will become increasingly scarce. (Schweller, 2011)

Second, interdependent hegemony reveals a mutually enforcing nexus between China's economic success and the existing global hard and normative power structures. Figure 1 below shows that Chinese economic power together 


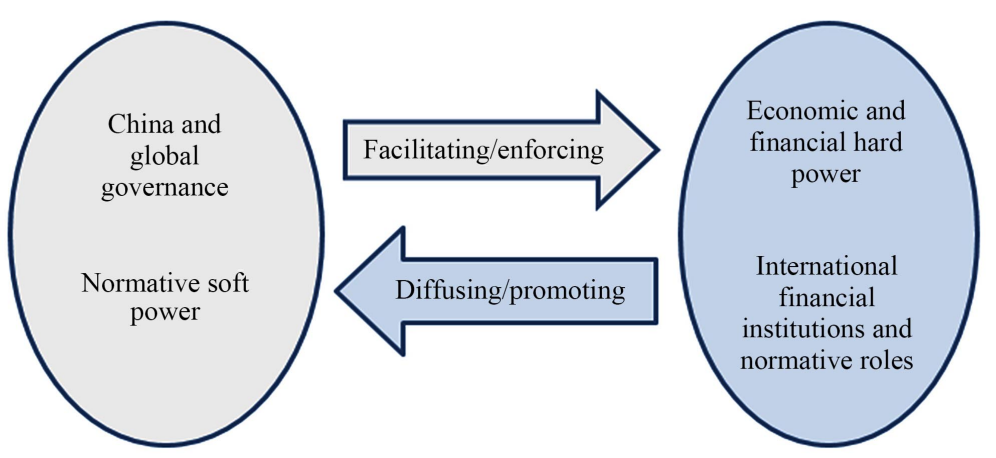

Figure 1. A positive circle of Chinese hard power, normative power, and soft power. (The author's own figure.)

with China's active role in international financial institutions and the country's increasing normative soft power in global governance are mutually reflective processes.

Third, interdependent hegemony leads the world into a post-hegemony and post-unilateral era in which there will be no hegemonic or unilateral norms and no values defined by one single country (the US) or by a core cultural civilization (the West). The rise of China is not only breaking up the monopoly of the West in political, economic, and technological hard power, but is also challenging many aspects of the existing world order's "soft" component of "normative" power. China is clearly an emerging "normative power" which is able to influence the policy behavior and attitudes of other states through the power of attraction. What distinguishes China from other (Western) normative powers is that rather than expecting other countries to comply with their own norms and values, China is aiming to construct "communities of practices" (Kavalski, 2013b) from which the outcomes are the product of negotiations and collective actions. This is also the rational spirit behind China's launching of the Asian Infrastructure Investment Bank (AIIB) and the "one belt one road" initiative (the new Silk Road project).

Fourth, interdependent hegemony implies that the rise of China is opening for multiple interpretations of the factors that are conducive to economic development. It can be argued that the key foundations of China's soft power during the past three decades have been the country's politics of sustained economic growth and poverty reduction, the resilient capacity and adaptability of the Chinese party-state when encountering changing political and economic environments, and China's ability to sustain its hegemony through periods of crises and transformation. It is globally recognized that "China has lifted more people out of poverty than anywhere else in the world: its per capita income increased fivefold between 1990 and 2000, from $\$ 200$ to $\$ 1000$. Between 2000 and 2010 Chinese per capita income also rose by the same rate, from $\$ 1000$ to $\$ 5000$, moving China into the ranks of middle-income countries" (Stuart, 2015). China has also made rapid advances in education, science, research, and especially in national infrastructure. Today, the Chinese government is committed to using its consi- 
derable governing capacity and competence to reduce inequality and clean up corruption and the environment. Underneath the Chinese success and behind the Chinese development model are implicit soft power implications.

Among the implications, "authoritarian resilience" is one of the strongest enduring features of the Chinese political culture, characterized by dynamic adaptive skills and greater institutional capacity for political survival (Nathan, 2003). Beijing's unique authoritarian deliberative mode of governance, including both input and output decision-making processes, is embedded with a "deliberative mechanism" which enables both party-government officials and the general public to use deliberation rather than power-struggle as the basis for their consensus (He, 2014). What can be regarded as "norm diffusion" from the Chinese success is the role of the socio-cultural and political "embeddedness" reflected by the unique embedded integration of state-market-society relations (Li, 2016b). In this context, Chinese soft power may have less to do with the attraction of the Chinese political system and cultural values and more to do with China as a metaphor for "doing it your own way" or an example of what can be done (Breslin, 2010).

Since soft power presumes a value-embedded identity capable of setting certain norms of social and political conduct on the basis of externalizing internal norms and projecting them at a global scale, China's economic success is generating global rethinking on the question as to whether economic development is more conditioned by the political architecture of Western democracy or by the professional management of Chinese governance. For developing countries, China's hard power achievement as an alternative economic development model seems to be the major source of attraction; however, it is impossible to separate hard material factors from the soft attraction to values and world-views (Breslin, 2011). Therefore, the Chinese development experience is opening for multiple interpretations and explanations regarding mechanisms that cause nations to grow, and regarding the set of mutually dependent relationships between property rights and economic growth, between the rule of law and a market economy, between a free currency flow and an economic order, and, most importantly, and between democracy and development. These norms and values should not be defined by the existing hegemonic powers alone, and they are becoming "interdependent", i.e. open, less rigid, and non-universal.

The underlined values diffusing from the "Chinese model" (Ramo, 2006), such as adherence to national self-determination, a strong role of the party and state, gradual reform and innovation to achieve economic growth, and international non-intervention, have been normalized as the "Beijing Consensus", and have "begun to remake the whole landscape of international development, economics, society and, by extension, politics" (Ramo, 2006). Many serious research studies disclose the effect of China's accumulation of its soft power presence in Africa. China's emergence as an alternative aid donor, investor, and economic partner seems to be one of the major soft power sources of attraction for other developing states. The absence of conditionality as a "Chinese norm" in China's interna- 
tional aid in Africa can be seen as a feature of Beijing's soft power, because such a norm of unconditionality refuses to build aid policies upon other countries' sovereignty, economic model, governance pattern, or political culture (Hubbard, 2008). However, many Western observers and policy-makers appraise Chinese international aid policy very critically.

Chinese soft power investment in Africa and the effect on local attitudes have been well documented by Deborah Brautigam (2010), a long-time observer of Africa and China, who demonstrates that Africans are generally receptive to China's developmental approach and treasure the longstanding historical connections built over decades with their Chinese partners; Africans also feel that China shows Africa far more understanding, sympathy and respect than paternalistic Western countries. Kenneth King, who has been conducting research on Africa for 30 years, focuses on China's specific soft-power strength in Africa, particularly in educational projects (King, 2013). He points out that Chinese language teaching in Africa is increasing on a rapid and grand scale, and is being followed by thousands of scholarships that help send young Africans to study at Chinese universities. Professional and business training programs are bringing thousands of African business people to China for learning experiences. These education efforts are aiming to show Africans how China does things, not to dictate Africans how they should do things. Moreover, China's long-committed medical teams and active health diplomacy are generating positive socio-political influence in Africa (Thompson, 2005).

\section{Conclusion}

The debate on the rise of China is entering a new stage, and so is the discussion on China's soft power. Beijing is struggling to grow and nurture its soft power capabilities in order to create an image of a benevolent global superpower. Already in the early 1990s, Samuel Huntington noted that non-Western civilizations including China, "increasingly have the desire, the will and the resources to shape the world in non-Western ways" (Huntington, 1993). Only in recent years, it has been increasingly acknowledged that China's engagement with other regions is already generating distinct socialization dynamics in the international system, and that therefore China is gradually taking the role of a norm-maker.

The conclusion of this paper on Chinese soft power has two implications. First, the source of Chinese soft power cannot be conceptualized merely in terms of popular culture, mass media, and political values. The emphasis on the source of Chinese soft power should be placed on the inseparable combination and interdependence of material hard power and ideational soft power. In other words, Chinese soft power does not play an independent role; rather, it is a byproduct, a reflection, or an expanded consequence of China's material and structural power. For example, the appreciation of Chinese traditional culture as the source of soft power cannot be achieved without understanding its role in China's economic success, or vice versa. In other words, the rise of China's soft power is shaped less by the state-led deliberate promotion of its cultural image, nation 
branding, and public diplomacy, but more by the country's economic success and the normative expansion of its global financial role. Second, the worldwide debate on Chinese soft power in the current era of "interdependent hegemony" (or "intertwined hegemony") reflects a constant process of shaping and reshaping the world order in which China is not only breaking up the monopoly of the West in political, economic and technological hard power, but is also challenging many aspects of the existing world order's "norm-setting" soft power.

On the basis of examination through the lens of different theories and the analysis of different empirical examples, the paper concludes that soft power with Chinese characteristics, i.e. norms, values, institutions and policies, is growing and is intertwined in the emerging world order, not as a result of deliberate promotion, but as a result of China's global economic rise and its increasing institutional roles and norm diffusion. The reason is that "shaping power" in the current capitalist world order is essentially determined by the system's modus operandi. That is to say, if China's economic development remained to be successful in the long run, the external expansion of Chinese economic power, especially its overseas aid, investment and trade, would eventually cause Chinese policies and practices, such as its financial and currency policies and its development and aid policies, to become "normal". Following China's integration with the economies of most countries and with millions of people outside of China's boundaries, Beijing will eventually become a global "normative power" both in the spheres of hard power (wage, price, credit, interest, cost and benefit) and in the domains of soft power (idea, norm, value, rule, and diplomacy).

As a result, the conventional notion of "soft power" or "normative power" will have to somehow accommodate the elements of "Chinese characteristics". The rise of Chinese hard power and normative soft power should not be perceived as Beijing's leverage to create an alternative political and economic world order, or to universalize Chinese norms, values and institutions. Rather, China is endeavoring to reshape the existing unilateral world order into a multilateral one.

\section{Conflicts of Interest}

The author declares no conflicts of interest regarding the publication of this paper.

\section{References}

Brautigam, D. (2010). The Dragon's Gift: The Real Story of China in Africa. London: Oxford University Press.

Breslin, S. (2010). China Engages Asia: The Soft Notion of China's "Soft Power". ETHOS, $8,5-11$.

https://www2.warwick.ac.uk/fac/soc/pais/people/breslin/research/sbreslin-china_engag es_asia-ethos_issue_8.pdf

Breslin, S. (2011). The Soft Notion of China's "Soft Power". Asia Programme Paper: ASP PP 2011/03. London: Chatham House.

https://www.chathamhouse.org/sites/files/chathamhouse/public/Research/Asia/0211pp breslin.pdf 
Callahan, W. A., \& Barabantseva, E. (2012). China Orders the World: Normative Soft Power and Foreign Policy. Baltimore, MD: Johns Hopkins University Press.

Clark, I. (2014). International Society and China: The Power of Norms and the Norms of Power. The Chinese Journal of International Politics, 7, 315-340.

https://doi.org/10.1093/cjip/pot014

Cox, R. W. (1981). Social Forces, States and World Orders: Beyond International Relations Theory. Millennium: Journal of International Studies, 10, 126-155. https://doi.org/10.1177/03058298810100020501

Cox, R. W. (1983). Gramsci, Hegemony and International Relations: An Essay in Method. Millennium: Journal of International Studies, 12, 162-175. https://doi.org/10.1177/03058298830120020701

Diez, T. (2005). Constructing the Self and Changing Others: Reconsidering "Normative Power Europe”. Millennium: Journal of International Studies, 33, 613-636. https://doi.org/10.1177/03058298050330031701

Feng, H. Y., \& He, K. (2015). Running the AIIB. Asia Dialogue. https://theasiadialogue.com/2015/05/28/the-aiib-what-will-china-do-next/

Gilpin, R. (2001). Global Political Economy: Understanding the International Economic Order. Princeton, NJ and Oxford: Princeton University Press. https://doi.org/10.1515/9781400831272

Gramsci, A. (1971). Selections from the Prison Notebooks. Q. Hoare, \& G. N. Smith (eds.), London: Lawrence \& Wishart.

Hayden, C. (2012). The Rhetoric of Soft Power: Public Diplomacy in Global Contexts. Lanham, MD: Lexington Books.

He, B. G. (2014). Deliberative Culture and Politics: The Persistence of Authoritarian Deliberation in China. Political Theory, 42, 58-81.

Hubbard, P. (2008). Chinese Concessional Loan. In R. Rotberg (Ed.), China into Africa: Trade, Aid, and Influence (pp. 217-230). Washington DC: Brookings Institution Press.

Huntington, S. P. (1993). The Clash of Civilizations? Foreign Affairs, 72, 22-49. https://doi.org/10.2307/20045621

Huntington, S. P. (1996). The Clash of Civilizations and the Remaking of World Order. London: Penguin Books Ltd.

Kavalski, E. (2013a). The Struggle for Recognition of Normative Powers: Normative Power Europe and Normative Power China in Context. Cooperation and Conflict, 48, 247-267. https://doi.org/10.1177/0010836713485386

Kavalski, E. (2013b). Chinese Normative Communities of Practice: Comparative Study of China's Relational Governance of Africa and Central Asia. In X. Li, \& O. Farah (Eds.), China-Africa Relations in an Era of Great Transformation (pp. 49-70). Farnham: Ashgate Publisher.

Keohane, R. (1984). After Hegemony: Cooperation and Discord in the World Political Economy. Princeton, NJ: Princeton University Press.

Kindleberger, C. (1973). The World in Depression, 1929-1939. Los Angeles, CA: University of California Press.

King, K. (2013). China's Aid and Soft Power in Africa (African Issues). Melton: James Currey.

Lanteigne, M. (2005). China and International Institutions. London: Routledge. https://doi.org/10.4324/9780203018378

Li, X. (2016a). Conceptualizing the Dialectics of China's Presence in Africa. In A. Arkhangelskaya, \& J. van der Merwe (Eds.), Emerging Powers in Africa: A New Wave in the Relationship (pp. 77-106). London: Palgrave Macmillan. 
Li, X. (2016b). Understanding China's Economic Success: "Embeddedness" with Chinese Characteristics. Asian Culture and History, 8, 18-31. https://doi.org/10.5539/ach.v8n2p18

Li, X. (2016c). From "Hegemony and World Order" to "Interdependent Hegemony and World Reorder". In S. Christensen, \& X. Li (Eds.), Emerging Powers, Emerging Markets, Emerging Societies: Global Responses (pp. 30-54). London: Palgrave Macmillan. https://doi.org/10.1007/978-1-137-56178-7_2

Lukes, S. (2005). Power: A Radical View. New York: Palgrave Macmillan. https://doi.org/10.1007/978-0-230-80257-5

Manners, I. (2002). Normative Power Europe: A Contradiction in Terms? Journal of Common Market Studies, 40, 235-258. https://doi.org/10.1111/1468-5965.00353

Nathan, A. J. (2003). Authoritarian Resilience. Journal of Democracy, 14, 6-17. https://doi.org/10.1353/jod.2003.0019

Nye, J. (1990). Soft Power. Foreign Policy, 80, 153-171. https://doi.org/10.2307/1148580

Nye, J. (2004). Power in the Global Information Age: From Realism to Globalization. London: Routledge. https://doi.org/10.4324/9780203507292

Nye, J. (2005). Soft Power: The Means to Success in World Politics. New York: Public Affairs.

Nye, J. (2009). Understanding International Conflicts. New York: Pearson.

Peng, Z. Z., \& Sow, K. T. (2016). The AIIB and China's Normative Power in International Financial Governance Structure. Chinese Political Science Review, 1, 736-753. https://doi.org/10.1007/s41111-016-0042-y

Ramo, J. C. (2006). The Beijing Consensus. London: The Foreign Policy Centre.

Rothman, S. B. (2011). Revising the Soft Power Concept: What Are the Means and Mechanisms of Soft Power? Journal of Political Power, 4, 49-64. https://doi.org/10.1080/2158379X.2011.556346

Runciman, D. (2018). China's Challenge to Democracy. Wall Street Journal, April 26. https://www.wsj.com/articles/chinas-challenge-to-democracy-1524756755

Schweller, R. L. (2011). Emerging Powers in an Age of Disorder. Global Governance, 17, 285-297. https://doi.org/10.1163/19426720-01703002

Simon, R. (1982). Gramsci's Political Thought. London: Lawrence and Wishart.

Simonyi, A., \& Saunders, P. J. (2015). Eliminating the Hard/Soft Power Dichotomy. In A. Jehan, \& A. Simonyi (Eds.), Smarter Power: The Key to a Strategic Transatlantic Partnership (pp. 13-30). Washington DC: Center for Transatlantic Relations, Johns Hopkins University.

Strand, J. R., Flores, E. M., \& Trevathan, M. W. (2016). China's Leadership in Global Economic Governance and the Creation of the Asian Infrastructure Investment Bank. Rising Powers Quarterly, 1, 55-69.

Stuart, E. (2015). China Has Almost Wiped Out Urban Poverty. Now It Must Tackle Inequality. The Guardian, August 15.

https://www.theguardian.com/business/economics-blog/2015/aug/19/china-poverty-in equality-development-goals

Thompson, D. (2005). China's Soft Power in Africa: From the "Beijing Consensus" to Health Diplomacy. China Brief, 5, 1-4.

https://jamestown.org/program/chinas-soft-power-in-africa-from-the-beijing-consens us-to-health-diplomacy

Vangeli, A. (2018). A Framework for the Study of the One Belt One Road Initiative as a Medium of Principle-Diffusion. In X. Li (Ed.), Mapping China's One Belt One Road Initiative (pp. 57-89). London: Palgrave Macmillan.

https://doi.org/10.1007/978-3-319-92201-0_3 
Wallerstein, I. (1979). The Capitalist World-Economy. New York: Cambridge University Press.

Wallerstein, I. (2004). World-Systems Analysis: An Introduction. Durham: Duke University Press. https://doi.org/10.1215/9780822399018

Winter, T. (2016). One Belt, One Road, One Heritage: Cultural Diplomacy and the Silk Road: The Cultural Aspects of the Belt and Road could Forever Reshape Regional Politics and Security. The Diplomat, March 29.

http://thediplomat.com/2016/03/one-belt-one-road-one-heritage-cultural-diplomacy-a nd-the-silk-road

Yan, X. T. (2007). The Core of Soft Power Is Political Power. Xinhuanet, May 23.

Yang, J. M. (2015). China's "New Diplomacy” under the Xi Jinping Administration. China Quarterly of International Strategic Studies, 1, 1-17. https://doi.org/10.1142/S2377740015500013

Zhu, F. (2007). China Should Give Priority to the Rise of Soft Power. Global Times, April 30. 